\title{
The clinical value of serum hepatic parenchyma cell volume- normalized hepatitis $B$ surface antigen levels in hepatitis $B$ e antigen -positive and -negative chronic hepatitis $B$ patients
}

\author{
Lei Tan ${ }^{1 \#}$, Shi-Lei $\mathrm{Xu}^{2 \#}$, Zhi-Shuo Mo ${ }^{3,4}$, Jian-Rong Liu ${ }^{5}$, Wei-Qiang Gan ${ }^{3,4}$, Jie-Huan Chen ${ }^{6}$, \\ Zhi-Liang Gao ${ }^{3,4}$, Ze-Qian $\mathbf{W u}^{3,4}$
}

${ }^{1}$ Department of Medical Ultrasonic, the Third Affiliated Hospital of Sun Yat-sen University, Guangzhou, China; ${ }^{2}$ Department of General Surgery, The Third Affiliated Hospital, Sun Yat-sen University, Guangzhou, China; ${ }^{3}$ Department of Infectious Diseases, the Third Affiliated Hospital of Sun Yat-sen University, Guangzhou, China; ${ }^{4}$ Key Laboratory of Topical Disease Control, Sun Yat-sen University, Ministry of Education, Guangzhou, China; ${ }^{5}$ Surgical and Transplant Intensive Care Unit, the Third Affiliated Hospital of Sun Yat-sen University, Guangzhou, China; ${ }^{6}$ Department of Ultrasound, Binhaiwan Central Hospital of Dongguan, Dongguan, China

Contributions: (I) Conception and design: ZQ Wu; (II) Administrative support: ZL Gao; (III) Provision of study materials or patients: All authors; (IV) Collection and assembly of data: L Tan, ZS Mo; (V) Data analysis and interpretation: L Tan; (VI) Manuscript writing: All authors; (VII) Final approval of manuscript: All authors.

\#These authors contributed equally to this work.

Correspondence to: Ze-Qian Wu; Zhi-Liang Gao. Department of Infectious Diseases, the Third Affiliated Hospital of Sun Yat-sen University, No. 600 Tianhe Road, Guangzhou 510630, China. Email: wuzeqian@mail.sysu.edu.cn; gaozl@mail.sysu.edu.cn.

Background: While serum hepatitis B surface antigens (HBsAg) play an important role in the diagnosis and assessment of treatment results of hepatitis B virus (HBV) infections, it remains unclear whether HBsAg levels normalized to hepatic parenchymal cell volume (HPCV) is a superior indicator of disease state. This study compared the absolute and HPCV-normalized serum HBsAg levels in hepatitis B e antigen (HBeAg)positive and HBeAg-negative patients with chronic hepatitis $\mathrm{B}(\mathrm{CHB})$.

Methods: Patients admitted to our institution with $\mathrm{CHB}$ were retrospectively included and categorized into the HBeAg-positive and HBeAg-negative groups. HPCV was calculated based on pathological examination of liver biopsy specimens and theory of sphere geometry. The difference between HBsAg levels and HBsAg normalized to HPCV, and also correlation between HBsAg levels and liver inflammation and fibrosis was analyzed.

Results: Absolute HBsAg levels ( $\mathrm{P}=0.004)$, but not HPCV-normalized HBsAg levels $(\mathrm{P}=0.071)$ were significantly higher in $\mathrm{HBeAg}$-positive patients compared to $\mathrm{HBeAg}$-negative patients. In $\mathrm{HBeAg}$-positive CHB patients, absolute HBsAg levels were positively correlated with liver inflammation grade $(\mathrm{R}=0.285$, $\mathrm{P}=0.001)$ and hepatic fibrosis stage $(\mathrm{R}=0.351, \mathrm{P}<0.001)$, as were HPCV-normalized HBsAg levels $(\mathrm{R}=0.640$ and 0.742, both, $\mathrm{P}<0.001)$. However, in HBeAg-negative CHB patients, only HPCV-normalized HBsAg level were correlated with liver inflammation grade and hepatic fibrosis stage $(\mathrm{R}=0.640$ and 0.785 , both, $\mathrm{P}<0.001)$.

Conclusions: HPCV-normalized serum HBsAg levels, rather than absolute HBsAg levels, were positively correlated with liver inflammation grade and hepatic fibrosis stage in both $\mathrm{HBeAg}$-positive and $\mathrm{HBeAg}-$ negative CHB patients. Thus, HPCV-normalized HBsAg levels may more accurately reflect the pathological progress of $\mathrm{CHB}$ patients compared to absolute HBsAg levels.

Keywords: Serum hepatitis B surface antigens level (serum HBsAg level); hepatic parenchyma cell volume (hepatic cell quantities); liver inflammation grades; hepatic fibrosis stages

Submitted Jul 09, 2021. Accepted for publication Sep 02, 2021.

doi: $10.21037 / \mathrm{atm}-21-3846$

View this article at: https://dx.doi.org/10.21037/atm-21-3846 


\section{Introduction}

Serum hepatitis B surface antigen (HBsAg) plays an important role in the diagnosis of hepatitis $B$ virus (HBV) infection, evaluation of disease treatment, and the assessment of hepatocellular carcinoma (HCC) risk. HBsAg clearance is the desired endpoint of antiviral therapy for patients with chronic hepatitis B (CHB) (1-3).

Persistent $\mathrm{HBV}$ infection is the result of interactions between virus replication and host immunity. Covalently closed circular DNA (cccDNA) is the source of hepatitis $\mathrm{B}$ virus (HBV) replication. HBV cannot be completely eliminated from infected hepatocytes due to the existence of intrahepatic cccDNA. Viral replication and HBsAg secretion change dynamically and there are positive correlations between intrahepatic ccc DNA and serum levels of HBV DNA and HBsAg. Serum HBsAg levels indirectly reflect viral replication and hepatocyte damage in CHB patients (4-6).

The biological functions of HBsAg and its role in the pathogenesis of CHB are not fully understood (7). Furthermore, hepatitis B e antigen ( $\mathrm{HBeAg}$ )-positive or -negative expression can vary markedly in patients with different degrees of liver inflammation and hepatic fibrosis. In CHB patients, persistent inflammation of hepatocytes results in progressive fibrosis, leading to fewer hepatic parenchymal cells, that is, a lower hepatic parenchymal cell volume (HPCV) available for HBV replication (8). Compared with $\mathrm{HBeAg}$-positive $\mathrm{CHB}$, $\mathrm{HBeAg}$-negative $\mathrm{CHB}$ is associated with lower serum levels of HBV DNA and HBsAg, but more severe hepatic inflammation and necrosis (9). However, it is not clear if the degree of fibrosis and HPCV influences circulating HBsAg levels. The paper argued $\mathrm{HPCV}$-normalized serum HBsAg in HBeAgpositive and $\mathrm{HBeAg}$-negative stages, which represent different periods in the natural history of chronic hepatitis B, as well as different hepatic fibrosis stages, which affects the hepatic parenchymal cell mainly.

A number of studies have suggested that markers of $\mathrm{CHB}$ infection, such as HBsAg levels, may more accurately indicate the stage of disease and viral replication when they are normalized to HPCV compared to using the absolute measured serum values $(10,11)$. This is because the number of hepatic parenchymal cells available for viral replication varies with the amount of liver fibrosis. Thus, the purpose of this study was to compare absolute serum HBsAg levels and HPCV-normalized HBsAg levels in HBeAg-positive and $\mathrm{HBeAg}$-negative $\mathrm{CHB}$ patients. We present the following article in accordance with the MDAR reporting checklist (available at https://dx.doi.org/10.21037/atm-213846).

\section{Methods}

\section{Patients}

Patients with CHB treated at the Department of Infectious Disease in our hospital between 2008 and 2012 were retrospectively enrolled in this study. Patients were included in if they: (I) presented with CHB infection and were treated at our institution; (II) had not received any prior antiviral treatments (to eliminate any influence of treatment on serum HBsAg levels and liver pathological diagnosis); (III) had appropriate testing to exclude hepatitis A, C, D, and $\mathrm{E}$ infection, and HIV infection; and (IV) had undergone a liver biopsy and pathological examination of the hepatic tissue. Liver biopsy is standard protocol at our institution for the diagnosis and evaluation of $\mathrm{CHB}$ infection.

\section{Ethics statement}

All procedures performed in this study involving human participants were in accordance with the Declaration of Helsinki (as revised in 2013). The study was approved by the local ethical committee of the Third Affiliated Hospital of Sun Yat-sen University (the ethical number: [2018]02429-01). All patients provided written informed consent for all treatments performed, including the liver biopsy, and for the use of their data for scientific investigations. All patient data were fully anonymized. None of the authors of this study were involved in the treatment or management of any of the patients included in the analysis.

\section{Serum HBs Ag and other antigen levels}

Serum antigen levels, including HBsAg levels, were measured with the Elecsys system (Roche Diagnostics GmbH, Mannheim, Germany) and the corresponding kits according to the manufacturer's instructions. The reference range for $\mathrm{HBsAg}$, hepatitis B surface antibody (anti-HBs), $\mathrm{HBeAg}$, hepatitis B e antibody (anti-HBe), and hepatitis B core antibody (anti-HBc) were as follows: HBsAg, $<1.0$ cut-off index (COI); anti-HBs, 0-10 IU/L; HBeAg, $<1.0$ COI; anti-HBe, $>1.0$ COI; anti-HBc, $>1.0$ COI (i.e., COI values $<1$ were defined as negative, and $\mathrm{COI}$ values $>1$ were defined as positive). 


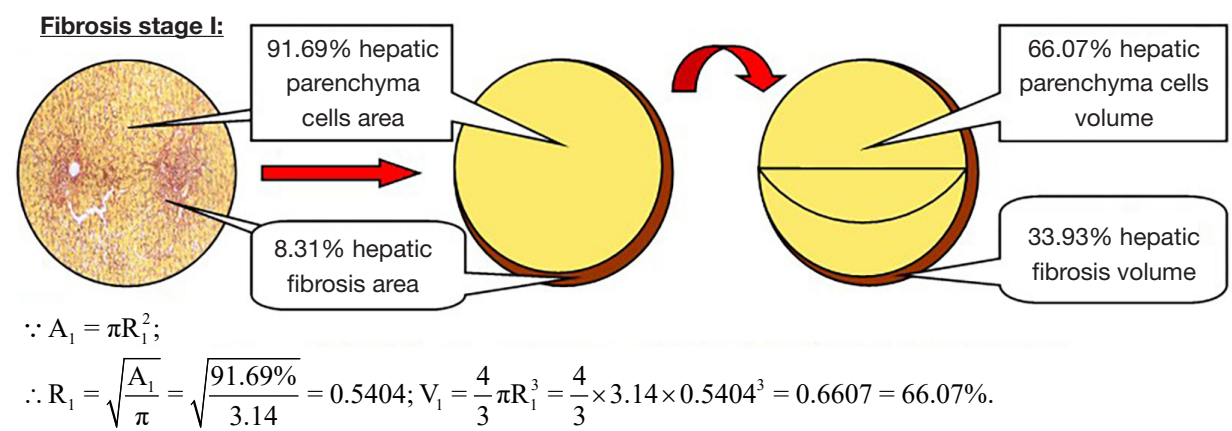

Fibrosis stage II:

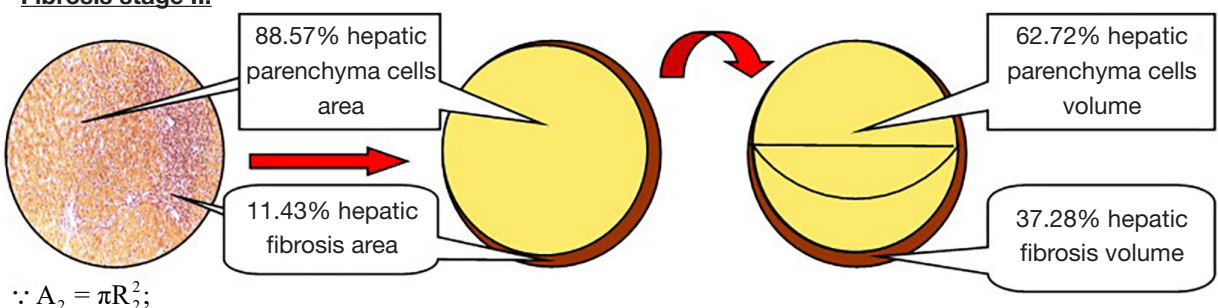

$\therefore \mathrm{R}_{2}=\sqrt{\frac{\mathrm{A}_{2}}{\pi}}=\sqrt{\frac{88.57 \%}{3.14}}=0.5311 ; \mathrm{V}_{2}=\frac{4}{3} \pi \mathrm{R}_{2}^{3}=\frac{4}{3} \times 3.14 \times 0.5311^{3}=0.6272=62.72 \%$.

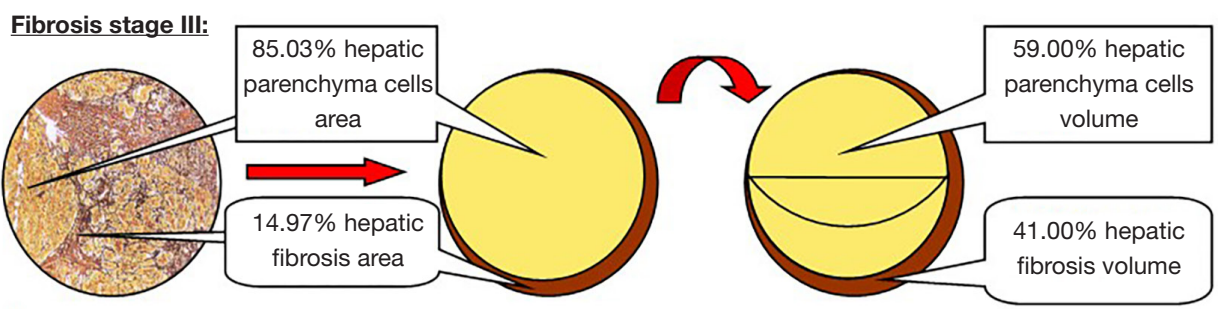

$\because \mathrm{A}_{3}=\pi \mathrm{R}_{3}^{2}$

$\therefore \mathrm{R}_{3}=\sqrt{\frac{\mathrm{A}_{3}}{\pi}}=\sqrt{\frac{85.03 \%}{3.14}}=0.5204 ; \mathrm{V}_{3}=\frac{4}{3} \pi \mathrm{R}_{3}^{3}=\frac{4}{3} \times 3.14 \times 0.5204^{3}=0.5900=59.00 \%$.

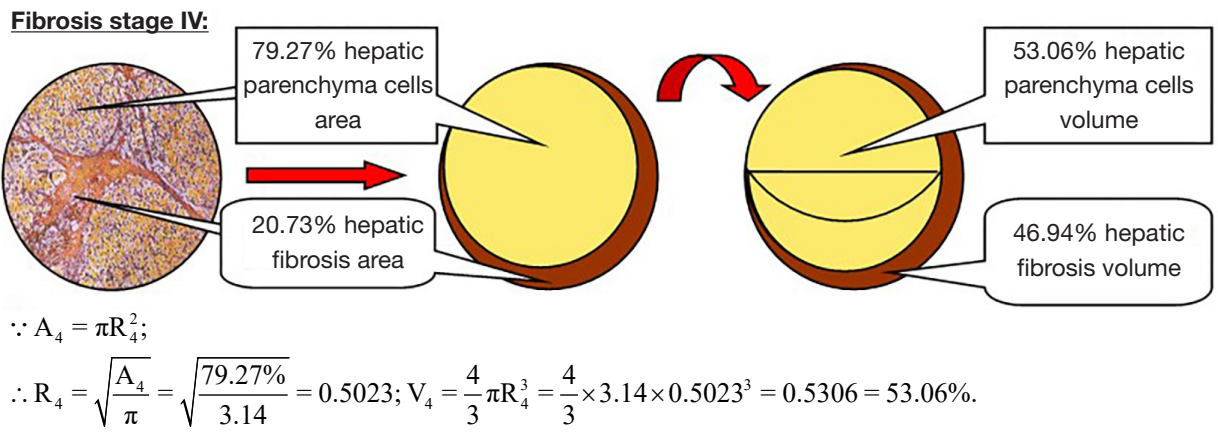

Figure 1 Illustration of the calculation of hepatic parenchyma cell volume in hepatic fibrosis stages 1-4.

\section{Liver histopathological diagnosis and measurement of bepatic fibrosis}

Liver biopsies were performed with an automatic biopsy gun using a $16 \mathrm{G}$ needle, guided by an Esaote AU4 color Doppler system (Esaote, USA). Biopsy specimens were approximately $20 \mathrm{~mm}$ in length. Tissue specimens were fixed with Bouin's solution and embedded in paraffin. Specimens were stained with hematoxylin-eosin (HE) and Masson's trichrome (Figure 1). Hepatic tissues were examined by pathologists experienced in liver diseases. 
Disease activity grade was staged using the modified histology activity index (12) and hepatic fibrosis was assessed using the Ishak fibrosis score (12).

The hepatic fibrosis proportion was measured with an automatic imaging analysis system (Kontron IBAS 2.5, Germany) using a Zeiss Axiotron microscope (Carl Zeiss AG, Germany) with a JVC-KY-F30B3-CCD lens (Japan) at $400 \times$ magnification. The percentage of fibrosis was calculated from randomly selected fields of view in the 4 corners and center of a section, and then the average of the 5 values was used for further analysis.

The results of our prior study indicated that the percentage of hepatic fibrosis in stage 1,2, 3, and 4 of the disease is $8.31 \% \pm 2.90 \%, 11.43 \% \pm 2.76 \%, 14.97 \% \pm 5.88 \%$, and $20.73 \% \pm 4.44 \%$, respectively (13).

\section{Calculation of HPCV using the proportion of fibrosis at different stages of hepatic fibrosis}

The liver consists of a majority of hepatic parenchyma cells, and a minority of sinusoidal endothelial cells, Kupffer cells, and mesenchymal cells. Therefore, the HPCV is approximately equivalent to the number of hepatocytes. Liver tissues were observed under a light microscope, and the field of view was circular in shape. The circular field of view consists of different proportions of hepatic parenchyma area and hepatic fibrosis area, which when summed equal $100 \%$ of the field of view (100\% rotundity). Based on our prior study (13), the proportion of hepatic parenchyma cell area in a field of view is equal to $100 \%$ of the area of each field of vision minus the area of hepatic fibrosis in the field of view. Thus, the percentage of hepatic parenchymal cell area in hepatic fibrosis stage 1 is $91.69 \%(100 \%-8.31 \%)$, $88.57 \%$ in stage $2(100 \%-11.43 \%), 85.03 \%$ in stage 3 $(100 \%-14.97 \%)$, and $79.27 \%$ in stage $4(100 \%-20.73 \%)$. These values were used for calculations in the current study.

The rotundity area formula is $A=\pi R^{2}$. The radii ( $R$ ) of internal smaller rotundity hepatic parenchyma cell area is equal to the square root of the ratio of internal smaller rotundity hepatic parenchyma cell area (A) to pi $(\pi)$, namely $\mathrm{R}=\sqrt{A / \pi}$. The radii of the rotundity area of hepatic parenchyma cell area in hepatic fibrosis stage 1 is $\sqrt{91.69 \% / 3.14}=0.5404$. In stage 2 , it is $\sqrt{88.57 \% / 3.14}=0.5311$, in stage 3 , it is $\sqrt{85.03 \% / 3.14}=0.5204$, and in stage 4 , it is $\sqrt{79.27 \% / 3.14}=0.5023$.

The volume of a sphere is expressed as volume $(\mathrm{V})$ $=4 / 3 \pi R^{3}$. Thus, the 3 -dimensional (3D) sphere HPCV volumes for hepatic fibrosis stage $1-4$ are as follows: $\mathrm{V}_{\text {stage } 1}=$
$4 / 3 \pi \mathrm{R}_{1}{ }^{3}=4 / 3 \times 3.14 \times 0.5404^{3}=66.07 \% ; \mathrm{V}_{\text {stage } 2}=4 / 3 \pi \mathrm{R}_{2}{ }^{3}=4 / 3 \times$ $3.14 \times 0.5311^{3}=62.72 \%, \mathrm{~V}_{\text {stage } 3}=4 / 3 \pi \mathrm{R}_{3}{ }^{3}=4 / 3 \times 3.14 \times 0.5204^{3}=$ $59.00 \%$; and $\mathrm{V}_{\text {stage } 4}=4 / 3 \pi \mathrm{R}_{4}{ }^{3}=4 / 3 \times 3.14 \times 0.5023^{3}=53.06 \%$. The rationale and process of calculations are shown in Figure 1.

\section{Calculation of HPCV-normalized serum HBs Ag levels}

To calculate HPCV-normalized HBsAg levels, serum HBsAg levels were divided by the HPCV percentage. This was performed as for hepatic fibrosis stages 1,2, 3, and 4 .

\section{Statistical analysis}

Statistical analyses were performed using SPSS version 20.0 software. Comparisons of absolute serum HBsAg levels and HPCV-normalized HBsAg between $\mathrm{HBeAg}$-positive and $\mathrm{HBeAg}$-negative $\mathrm{CHB}$ patients were performed using Student's independent t-test. The correlation between serum HBsAg levels (absolute and HPCV-normalized) and liver inflammation grades or hepatic fibrosis stage was examined using Pearson's correlation coefficient data, respectively. All analyses were 2-tailed, and a value of $\mathrm{P}<0.05$ was considered to be statistically significant.

\section{Results}

The correlation between patient characteristics and liver inflammation grade and hepatic fibrosis stage

A total of $254 \mathrm{CHB}$ patients were retrospectively enrolled in this study. There were $127 \mathrm{HBeAg}$-positive patients, including 104 males and 23 females, with a median age of $33.9 \pm 10.1$ years. There were $127 \mathrm{HBeAg}$-negative patients, consisting of 106 males and 21 females, with a median age of $39.6 \pm 9.7$ years. Liver inflammation grade was positively correlated with hepatic fibrosis stage in both $\mathrm{HBeAg}$-positive $(\mathrm{R}=0.841 ; \mathrm{P}<0.001)$ and HBeAg-negative $(\mathrm{R}=0.843 ; \mathrm{P}<0.001)$ patients (Table 1). In the majority of patients, more severe liver inflammation was associated with more severe hepatic fibrosis.

\section{Analysis of the absolute and HPCV-normalized HBs Ag levels in HBeAg-positive and HBeAg-negative CHB patients}

Absolute serum HBsAg levels in HBeAg-positive CHB patients were significantly higher than that observed in $\mathrm{HBeAg}$-negative patients $(\mathrm{P}=0.004)$. However, HPCVnormalized serum $\mathrm{HBsAg}$ levels were not significantly different between the HBeAg-positive and the HBeAgnegative groups ( $\mathrm{P}=0.071$; Table 2$)$. To confirm these results, 
multivariate linear regression models adjusted for patient gender, age, liver inflammation grade, and hepatic fibrosis stage were performed. The estimated regression coefficients of $\mathrm{HBeAg}$ status (negative as reference) with absolute serum HBsAg level $\left(\log _{10} \mathrm{COI}\right)$ and $\mathrm{HPCV}$-normalized serum HBsAg level $\left(\log _{10} \mathrm{COI}\right)$ were -0.15 (95\% CI: -0.24 to $-0.05, \mathrm{P}=0.003)$ and -0.25 (95\% CI: -0.41 to -0.09 , $\mathrm{P}=0.002)$, respectively.

\section{Pearson correlation analyses of serum HBs Ag with liver inflammation grade and hepatic fibrosis stage in $\mathrm{HBeAg}$ - positive and HBeAg-negative CHB patients}

In HBeAg-positive CHB patients, absolute serum HBsAg

Table 1 Liver inflammation grades and hepatic fibrosis stages in $127 \mathrm{HBeAg}$-positive and $127 \mathrm{HBeAg}$-negative chronic hepatitis B patients

\begin{tabular}{|c|c|c|c|c|c|}
\hline \multirow{2}{*}{ Liver inflammation grades } & \multicolumn{4}{|c|}{ Hepatic fibrosis stages } & \multirow{2}{*}{ Total } \\
\hline & $\mathrm{S}_{1}$ & $\mathrm{~S}_{2}$ & $\mathrm{~S}_{3}$ & $\mathrm{~S}_{4}$ & \\
\hline \multicolumn{6}{|l|}{$\mathrm{HBeAg}(+)$} \\
\hline $\mathrm{G}_{1}$ & 15 & 1 & 0 & 0 & 16 \\
\hline $\mathrm{G}_{2}$ & 12 & 35 & 5 & 0 & 50 \\
\hline $\mathrm{G}_{3}$ & 0 & 5 & 22 & 9 & 36 \\
\hline $\mathrm{G}_{4}$ & 0 & 2 & 3 & 20 & 25 \\
\hline Total & 27 & 41 & 30 & 29 & 127 \\
\hline \multicolumn{6}{|l|}{ HBeAg (-) } \\
\hline $\mathrm{G}_{1}$ & 29 & 3 & 0 & 1 & 33 \\
\hline $\mathrm{G}_{2}$ & 9 & 26 & 5 & 1 & 41 \\
\hline $\mathrm{G}_{3}$ & 0 & 1 & 17 & 9 & 27 \\
\hline $\mathrm{G}_{4}$ & 0 & 1 & 6 & 19 & 26 \\
\hline Total & 38 & 31 & 28 & 30 & 127 \\
\hline
\end{tabular}

Correlation analysis of liver inflammation grades and hepatic fibrosis stages: $\mathrm{HBeAg}$-positive, $\mathrm{R}=0.841, \mathrm{P}<0.001$; $\mathrm{HBeAg}$ negative, $\mathrm{R}=0.843, \mathrm{P}<0.001$. $\mathrm{HBeAg}$, hepatitis $\mathrm{B}$ e antigen. levels correlated positively with both liver inflammation grade $(\mathrm{R}=0.285, \mathrm{P}=0.001)$ and hepatic fibrosis stage $(\mathrm{R}=0.351, \mathrm{P}<0.001)$. While HPCV-normalized HBsAg levels also showed a positive correlation with liver inflammation grade $(\mathrm{R}=0.640, \mathrm{P}<0.001)$ and hepatic fibrosis stage $(\mathrm{R}=0.742, \mathrm{P}<0.001)$ (Figure 2). In $\mathrm{HBeAg}$-negative $\mathrm{CHB}$ patients, there was no correlation between absolute serum HBsAg levels and liver inflammation grade $(\mathrm{R}=0.035$, $\mathrm{P}=0.698)$ nor hepatic fibrosis stage $(\mathrm{R}=0.055, \mathrm{P}=0.540)$. However, there was a significant positive correlation between HPCV-normalized HBsAg levels and liver inflammation grade $(\mathrm{R}=0.640, \mathrm{P}<0.001)$ and hepatic fibrosis stage $(\mathrm{R}=0.785, \mathrm{P}<0.001)$ (Figure 2$)$.

\section{Discussion}

Serum HBV DNA, HBsAg, and HBeAg levels are the most convenient and reliable indicators of viral replication in CHB patients (14). The European Association for the Study of the Liver (EASL) 2017 Clinical Practice Guidelines classified CHB infection into the following 5 stages: (I) HBeAg-positive chronic infection; (II) HBeAgpositive chronic hepatitis; (III) HBeAg-negative chronic infection; (IV) HBeAg-negative chronic hepatitis; and (V) HBsAg-negative phase (15). The seroconversion from $\mathrm{HBeAg}$ to HBeAb is often accompanied by HBV DNA suppression and remission of pathological damage (15). While there have been many studies examining changes of serum HBsAg and the degree of liver inflammation and hepatic fibrosis in CHB patients, clear associations have not been found (16-19). However, it should be noted that the impact of the degree of fibrosis on HPCV or the effective hepatic cell number was considered in the aforementioned studies. In the $\mathrm{HBeAg}$-positive and $\mathrm{HBeAg}$-negatives stage of $\mathrm{CHB}$ infection, liver injury is caused by inflammation and the associated fibrosis formation, and persistent inflammation results in progressive fibrosis. As fibrosis increases, the effective hepatic cell quantity (HPCV) decreases. Undoubtedly,

Table 2 Analysis of the absolute and HPCV-normalized serum HBsAg levels in HBeAg-positive and HBeAg-negative CHB patients

\begin{tabular}{lrrrr} 
& HBeAg-positive CHB & HBeAg-negative CHB & $\mathrm{t}$ & $\mathrm{P}$ \\
\hline Serum HBsAg (log10 COI) & $3.70 \pm 0.37$ & $3.56 \pm 0.38$ & 2.871 & 0.004 \\
Serum HBsAg apportioned by the same HPCV $\left(\log _{10} \mathrm{COI}\right)$ & $6.15 \pm 0.83$ & $6.00 \pm 0.88$ & 1.815 & 0.071 \\
\hline
\end{tabular}

HPCV, hepatic parenchyma cell volume; HBsAg, hepatitis B surface antigen; HBeAg, hepatitis B e antigen; CHB, chronic hepatitis B; COI, cut-off index. 

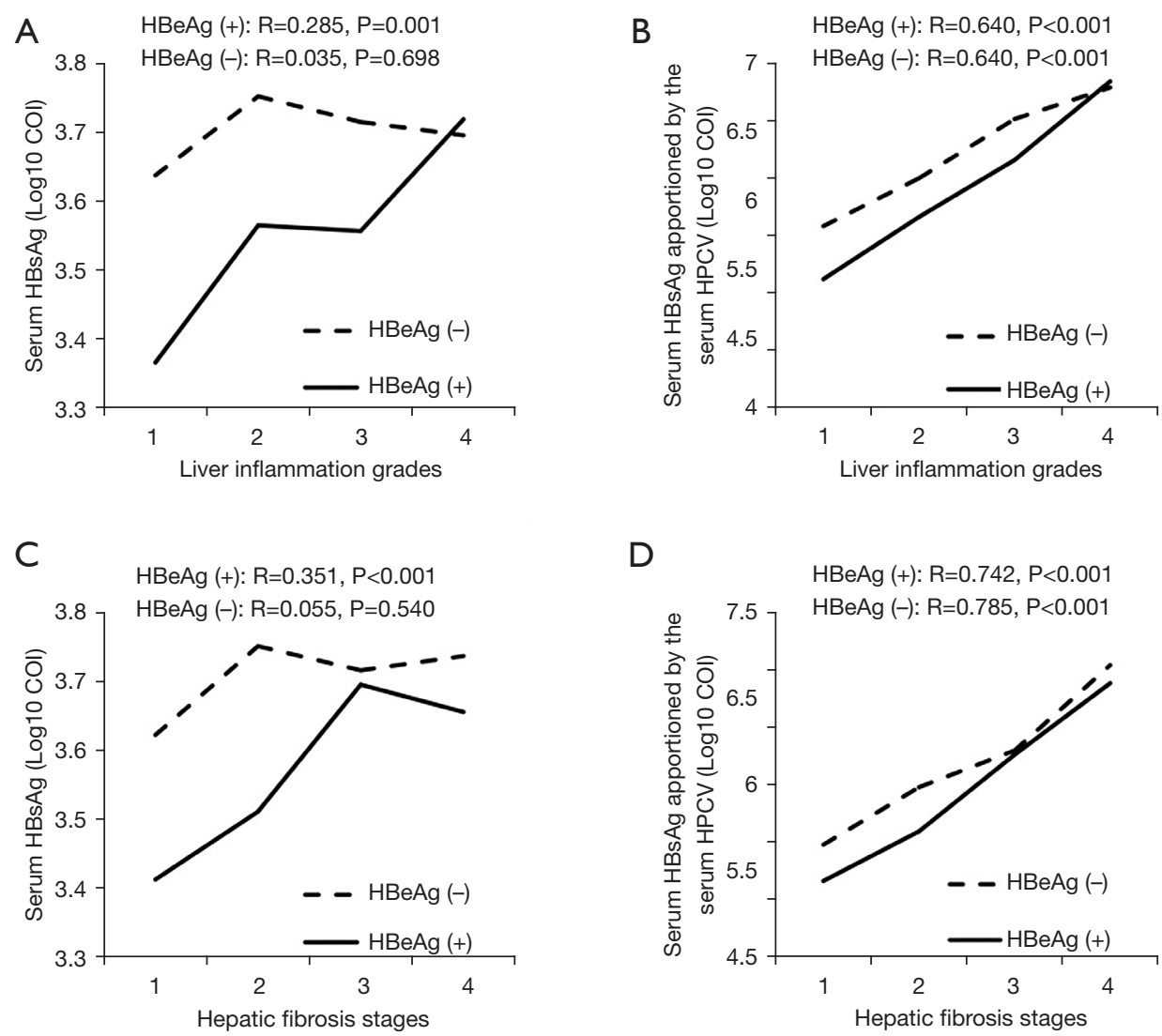

Figure 2 Correlation analyses of (A) absolute serum HBsAg levels and (B) HPCV-normalized HBsAg levels with liver inflammation grade in HBeAg-positive and HBeAg-negative CHB patients. Correlation analyses of (C) absolute serum HBsAg levels and (D) HPCV-normalized $\mathrm{HBsAg}$ levels with hepatic fibrosis stage in HBeAg-positive and HBeAg-negative CHB patients. HBsAg, hepatitis B surface antigen; HPCV, hepatic parenchyma cell volume; $\mathrm{HBeAg}$, hepatitis B e antigen; $\mathrm{CHB}$, chronic hepatitis $\mathrm{B}$.

when there are fewer hepatic parenchyma cells for host HBV replication, HBsAg production will be reduced, lowering serum HBsAg levels $(20,21)$.

Our results showed that the absolute serum HBsAg levels were higher in $\mathrm{HBeAg}$-positive $\mathrm{CHB}$ patients than in HBeAg-negative CHB patients. However, HPCVnormalized HBsAg levels were not different between HBeAg-positive and HBeAg-negative patients. This result suggested that $\mathrm{HBeAg}$ seroconversion does not truly reflect suppression of $\mathrm{HBV}$ replication or HBsAg synthesis, and HBeAg status need not be considered in HBV antiviral therapy. This finding is consistent with the current guidelines of HBV treatment (15) in which the HBeAg-positive and HBeAg-negative CHB patients are no longer treated differently. HBeAg may exhibit spontaneous serological conversion in some CHB patients. However, this does not necessarily mean that viral replication in the body is immunologically controlled. HBeAg seroconversion can be related to mutations of the pro- $\mathrm{C}$ or $\mathrm{C}$ promoter regions, and in this case, active viral replication will still occur $(22,23)$. During the HBeAg-negative phase of CHB HBV replication, HBsAg expression in a single hepatocyte is not less than that observed in the HBeAg-positive phase. The mechanisms and extent of immune-mediated pathological damage are similar in HBeAg-positive and HBeAg-negative CHB.

Furthermore, our results demonstrated that in both $\mathrm{HBeAg}$-positive and HBeAg-negative $\mathrm{CHB}$ patients, HPCV-normalized serum HBsAg levels (i.e., hepatic cell quantity) were significantly positively correlated with liver inflammation grade and hepatic fibrosis stage. However, in $\mathrm{HBeAg}$-negative $\mathrm{CHB}$, absolute HBsAg levels were not correlated with liver inflammation grade and hepatic fibrosis stage. This finding suggested that the "natural decline" of detectable serum HBsAg in the natural course 
of $\mathrm{CHB}$ infection with seroconversion from $\mathrm{HBeAg}$ positive to $\mathrm{HBeAg}$-negative does not represent a reduction or stationary phase of viral replication, nor lessening of liver tissue injury. Instead, the results suggested that HBV replication in a single hepatocyte is more active, and thus, can aggravate immune-mediated pathological injury and potentially trigger the development of tumors (24). As such, the impact of liver inflammation and hepatic fibrosis on HPCV should be considered when treating HBeAgnegative $\mathrm{CHB}$ patients with low or declining serum $\mathrm{HBsAg}$ levels. To this end, non-invasive methods for the assessment of liver fibrosis, or liver biopsies, should be recommended for $\mathrm{HBeAg}$-negative CHB patients with low serum HBsAg levels and normal liver function. Effective antiviral therapy should be promptly administered based on the assessment of liver fibrosis and inflammation (25).

There were some limitations to this study. First, the HBsAg levels were not tested and reported using the worldwide recognized units $\mathrm{IU} / \mathrm{mL}$, and this is a major limitation to the present study. In addition, although HPCV-normalized HBsAg levels, rather than absolute HBsAg levels, were associated with inflammation and fibrosis in both $\mathrm{HBeAg}$-positive and $\mathrm{HBeAg}$-negative patients, the underlying mechanisms remain to be investigated in future studies.

\section{Conclusions}

In summary, HPCV-normalized HBsAg levels, rather than absolute HBsAg levels, were positively correlated with liver inflammation grade and hepatic fibrosis stage in both $\mathrm{HBeAg}$-positive and $\mathrm{HBeAg}$-negative $\mathrm{CHB}$ patients. HPCV-normalized HBsAg levels may provide more accurate information regarding disease status compared to absolute HBsAg levels in CHB patients.

\section{Acknowledgments}

Funding: This study was supported by the National Science and Technology Major Project (2018ZX10302204-002) and the National Natural Science Foundation of China (81672701).

\section{Footnote}

Reporting Checklist: The authors have completed the MDAR reporting checklist. Available at https://dx.doi. org/10.21037/atm-21-3846
Data Sharing Statement: Available at https://dx.doi. org/10.21037/atm-21-3846

Conflicts of Interest: All authors have completed the ICMJE uniform disclosure form (available at https://dx.doi. org/10.21037/atm-21-3846). The authors have no conflicts of interest to declare.

Ethical Statement: The authors are accountable for all aspects of the work in ensuring that questions related to the accuracy or integrity of any part of the work are appropriately investigated and resolved. All procedures performed in this study involving human participants were in accordance with the Declaration of Helsinki (as revised in 2013). The study was approved by by the local ethical committee of the Third Affiliated Hospital of Sun Yat-sen University (the ethical number: [2018]02-429$01)$. All patients provided written informed consent for all treatments performed, including the liver biopsy, and for the use of their data for scientific investigations. All patient data were fully anonymized.

Open Access Statement: This is an Open Access article distributed in accordance with the Creative Commons Attribution-NonCommercial-NoDerivs 4.0 International License (CC BY-NC-ND 4.0), which permits the noncommercial replication and distribution of the article with the strict proviso that no changes or edits are made and the original work is properly cited (including links to both the formal publication through the relevant DOI and the license). See: https://creativecommons.org/licenses/by-nc-nd/4.0/.

\section{References}

1. Martinot-Peignoux M, Lapalus M, Asselah T, et al. The role of HBsAg quantification for monitoring natural history and treatment outcome. Liver Int 2013;33 Suppl 1:125-32.

2. Martinot-Peignoux M, Lapalus M, Asselah T, et al. HBsAg quantification: useful for monitoring natural history and treatment outcome. Liver Int 2014;34 Suppl 1:97-107.

3. Fourati S, Pawlotsky JM. Recent advances in understanding and diagnosing hepatitis B virus infection. F1000Res 2016;5:F1000 Faculty Rev-2243.

4. Guner R, Karahocagil M, Buyukberber M, et al. Correlation between intrahepatic hepatitis $\mathrm{B}$ virus cccDNA levels and other activity markers in patients with HBeAgnegative chronic hepatitis B infection. Eur J Gastroenterol Hepatol 2011;23:1185-91. 
5. Locarnini S, Bowden S. Hepatitis B surface antigen quantification: not what it seems on the surface. Hepatology 2012;56:411-4.

6. Zeng LY, Lian JS, Chen JY, et al. Hepatitis B surface antigen levels during natural history of chronic hepatitis B: a Chinese perspective study. World J Gastroenterol 2014;20:9178-84.

7. Liang TJ. Hepatitis B: the virus and disease. Hepatology 2009;49:S13-21.

8. Lin CL, Kao JH. New perspectives of biomarkers for the management of chronic hepatitis B. Clin Mol Hepatol 2016;22:423-31.

9. Alexopoulou A, Karayiannis P. HBeAg negative variants and their role in the natural history of chronic hepatitis $\mathrm{B}$ virus infection. World J Gastroenterol 2014;20:7644-52.

10. Ke WM, Xie SB, Li XJ, et al. There were no differences in serum HBV DNA level between HBeAg-positive and $\mathrm{HBeAg-negative} \mathrm{chronic} \mathrm{hepatitis} \mathrm{B} \mathrm{with} \mathrm{same} \mathrm{liver}$ histological necroinflammation grade but differences among grades 1, 2, 3 and 4 apportioned by the same hepatic parenchyma cell volume. J Viral Hepat 2011;18:637-45.

11. Wu ZB, Cao H, Liu T, et al. Dynamic expression profile of HBsAg according to hepatic parenchyma cells' volume at different liver fibrosis stages in the immune clearance phase. Zhonghua Gan Zang Bing Za Zhi 2012;20:742-5.

12. Ishak $\mathrm{K}$, Baptista A, Bianchi L, et al. Histological grading and staging of chronic hepatitis. J Hepatol 1995;22:696-9.

13. Xie SB, Yao JL, Zheng SS, et al. The levels of serum fibrosis marks and morphometric quantitative measurement of hepatic fibrosis. Hepatobiliary Pancreat Dis Int 2002;1:202-6.

14. Diktas H, Karacaer Z, Özturk II, et al. Comparison of relationship between histopathological, serological and biochemical parameters in patients with chronic hepatitis B infection. Postgrad Med J 2016;92:693-6.

15. European Association for the Study of the Liver. Electronic address: easloffice@easloffice.eu; European Association for the Study of the Liver. EASL 2017 Clinical Practice Guidelines on the management of hepatitis B virus infection. J Hepatol 2017;67:370-98.

16. Xun YH, Zang GQ, Guo JC, et al. Serum hepatitis B

Cite this article as: Tan L, Xu SL, Mo ZS, Liu JR, Gan WQ, Chen JH, Gao ZL, Wu ZQ. The clinical value of serum hepatic parenchyma cell volume-normalized hepatitis B surface antigen levels in hepatitis B e antigen -positive and -negative chronic hepatitis B patients. Ann Transl Med 2021;9(18):1431. doi: 10.21037/atm-21-3846 surface antigen quantification as a useful assessment for significant fibrosis in hepatitis B e antigen-positive hepatitis B virus carriers. J Gastroenterol Hepatol 2013;28:1746-55.

17. Xie Q, Hu X, Zhang Y, et al. Decreasing hepatitis B viral load is associated with a risk of significant liver fibrosis in hepatitis B e antigen positive chronic hepatitis B. J Med Virol 2014;86:1828-37.

18. Martinot-Peignoux M, Carvalho-Filho R, Lapalus M, et al. Hepatitis B surface antigen serum level is associated with fibrosis severity in treatment-naïve, e antigen-positive patients. J Hepatol 2013;58:1089-95.

19. Wang H, Ru GQ, Yan R, et al. Histologic Disease in Chinese Chronic Hepatitis B Patients With Low Viral Loads and Persistently Normal Alanine Aminotransferase Levels. J Clin Gastroenterol 2016;50:790-6.

20. Wu ZQ, Tan L, Liu T, et al. Evaluation of changes of serum hepatitis B surface antigen from a different perspective. World J Gastroenterol 2015;21:2739-45.

21. Ke WM, Xie SB, Yu LN, et al. Decline of serum HBV DNA and no change apportioned by the same hepatic parenchyma cell volume from hepatic fibrosis stage 1 to stage 4 during the natural history of chronic hepatitis B. Intervirology 2008;51:235-40.

22. Quarleri J. Core promoter: a critical region where the hepatitis B virus makes decisions. World J Gastroenterol 2014;20:425-35.

23. Moradi A, Zhand S, Ghaemi A, et al. Mutations in precore and basal-core promoter regions of hepatitis $\mathrm{B}$ virus in chronic HBV patients from Golestan, Iran. Iran J Basic Med Sci 2014;17:370-7.

24. Weber A, Boege Y, Reisinger F, et al. Chronic liver inflammation and hepatocellular carcinoma: persistence matters. Swiss Med Wkly 2011;141:w13197.

25. Zhu P, Tang Y, Wang YM. Recommendations for APASL Clinical Practice Guidelines: management of hepatitis B (updated in 2015). Journal of Clinical Hepatology 2016;32:423-8.

(English Language Editor: J. Toeh) 